\title{
Effects of mechanical aeration on tambaqui farming (Colossoma macropomum) in excavated tanks
}

\section{Efeito da aeração mecânica sobre o cultivo de tambaqui (Colossoma macropomum) em viveiro escavado}

Raniere Garcez Costa Sousa ${ }^{* 1}$, Milene Muniz da Rocha ${ }^{1}$, Rute Bianchini Pontuschka ${ }^{1}$ \& Heitor Thury Barreiros Barbosa ${ }^{2}$

\footnotetext{
${ }^{1}$ Departamento de Ciências Pesqueiras, Programa de Pós-Graduação em Ciências Ambientais, Universidade Federal de Rondônia - Unir
${ }^{2}$ Departamento de Desenvolvimento Educacional. Instituto Federal da Educação, Ciência e Tecnologia do Amazonas, Presidente Figueiredo - Ifam

*E-mail: ranieregarcez@unir.br

Recebido: 22 de junho de 2017 / Aceito: 22 de setembro de 2017/ Publicado: 16 de dezembro de 2017

\begin{abstract}
In this study, we compared the development of tambaqui Colossoma macropomum in excavated tanks with and without mechanical aeration. The experiment was conducted in a semi-intensive system, which used two $600 \mathrm{~m}^{2}$ nurseries (tanks) populated with 500 juveniles, from September, 2014 to August, 2015. They were submitted to weekly biometry of 50 individuals and the follow-up on water quality control. At the end of the farming period, the final weight (1.96 $\pm 0.44 \mathrm{~kg}$ with aeration and $1.95 \pm 0.24 \mathrm{~kg}$ without aeration) and the other performance indicators were statistically similar $(\mathrm{p}>0.464)$. It is therefore concluded that the use of aerators is unnecessary for tambaqui farming in a semi-intensive system.
\end{abstract}

Keywords: Fish farming. Aerator. Fishery thecnology.

\begin{abstract}
Resumo Neste estudo, comparamos o desenvolvimento do tambaqui Colossoma macropomum em viveiros escavados com e sem aeração mecânica. $\mathrm{O}$ experimento foi conduzido em sistema semi-intensivo, usando dois viveiros de 600 $\mathrm{m}^{2}$, povoados com 500 juvenis, entre setembro de 2014 e agosto de 2015, submetidos à biometria semanal de 50 indivíduos e acompanhamento da qualidade da água. Ao final do cultivo, o peso final $(1,96 \pm 0,44 \mathrm{~kg}$ com aeração e $1,95 \pm 0,24 \mathrm{~kg}$ sem aeração) e demais indicadores de desempenho foram estatisticamente semelhantes ( $p>0,464)$. Conclui-se, portanto, que o uso de aeradores é desnecessário para o cultivo de tambaqui em sistema semi-intensivo.
\end{abstract}

Palavras-Chave: Piscicultura. Aerador. Tecnologia de pesca. 
Acta of Fisheries and Aquatic Resources

\section{Introduction}

The continuous expansion of fish farming has been due to two main factors, one of them is the increasing fish consumption and the other is due to the slump in natural stocks (Bombardelli, Syperreck \& Sanches, 2005; Macedo \& Sipauba-Tavares, 2010; Morais \& O'Sullivan, 2017). The rise in consumption of worldwide fisheries for human food exceeded 146 million tons in 2014 and it might reach 196 million tons in 2025 (FAO, 2016). As for Brazil, this projection means approximately 2 million tons of fisheries, which corresponds to an increase of $48.6 \%$ in relation to the production between the years of 2013 and 2015 . Among the Brazilian states, Rondônia stands out due to its capacity of tripling the production between the years of 2013 and 2015, achieving first place in the national ranking of fish producers (Batista \& PetrereJr., 2003; Kubitza, 2004; Costa, 2015; IBGE, 2015).

Among the species produced in Rondônia, the tambaqui (Colossoma macropomum Cuvier 1818) accounts for $28.1 \%$ (135.86 thousand tons) of the commercialized fish in 2015 (IBGE, 2015). This is a species with great adaptability to farming, noble meat and high acceptance on national and international market (Cartonilho \& De Jesus, 2011; Oliveira Sales \& Maia, 2013). The rise in production of tambaqui reflects the investments from private sector as well as the implementation of public policies by states such as Rondônia, which promoted the debureaucratization and the removal of taxation on environmental licensing, easy credit and ICMS (Tax on circulation of goods and services) reduction on fish and fish food, which made the state's production jump from 19 thousand to 63 thousand tons of tambaquis from the years of 2013 to 2014 (Pedroza-Fiho, Rodrigues \& Rezende, 2016).

The aerator, a device used to stir up and oxygenate the water (Thakre, Bhuyar \& Deshmukh, 2008) aims to increase the farm fishing productivity, ensuring concentrations of dissolved oxygen (DO) within the ideal range for the species chosen (Kepenyes \& Varadi, 1984; Boyd, 1998; Castro \& Souza, 2002; Kubitza, 2003; Vinatea, 2004; Maffezzolli \& Nuñer, 2006; El-Nemr \& El-Nemr, 2013). Nowadays, the market offers a great variety of models of this device, which vary according to the condition and/or the farming necessity (Boyd, 1998).

The researches on tambaqui farming are in a very advanced stage, involving protocols for transportation of living individuals up to $1 \mathrm{Kg}$ (Gomes, 2003), handling technologies (Melo, Izel \& Rodrigues, 2001; Izel \& Melo, 2004; Silva et al., 2014; Silva, 2015; Morais \& O’Sullivan, 2017), effluent treatment (Freitas et al., 2014) and others related to the productivity rise by using aerators (Izel et al., 2013; Pontes, 2013), object of this study. However, considering the few existing studies on the use of aerators for tambaqui farming in Brazil, the current research aims to evaluate the effect of mechanical aeration on the zootechnical development of this species in excavated tanks.

\section{Material and Methods}

This study was fully conducted at the Fishery Department at Universidade Federal de Rondônia, located in the municipality of Presidente Médici, the geographic coordinates are $11^{\circ} 10^{\prime} 34,26^{\prime \prime}$ S latitude and $61^{\circ}$ 53' 20,52' W longitude (Figure 1). Two excavated tanks were used for this experiment, T1 and T2, with an area of $600 \mathrm{~m}^{2}$ each and average depth of $1.40 \mathrm{~m}$. T1 tank was kept as the control nursery, without an aerator. In T2 tank a $1 \mathrm{Hp}$, three-phase, mechanical aerator was installed, capable of injecting $2.5 \mathrm{Kg} \mathrm{O} / \mathrm{h}$, which was kept in operation only for the period from 6:00 p.m. to 6:00 a.m. during all the experiment.

Before the populating process, the tanks were prepared according to the recommendations by Brazilian Agricultural Research Corporation (Embrapa, 2004). Later, 500 tambaqui juveniles were selected with average weight of $42.68 \pm 16.26 \mathrm{~g}$, equally divided for both tanks, corresponding to a $0.42 \mathrm{fish} / \mathrm{m}^{2}$ density. The food handling followed Gomes' recommendations (2003). From the populating process in September 2014 to the harvest in August 2015, and the total was 12 farming months. 


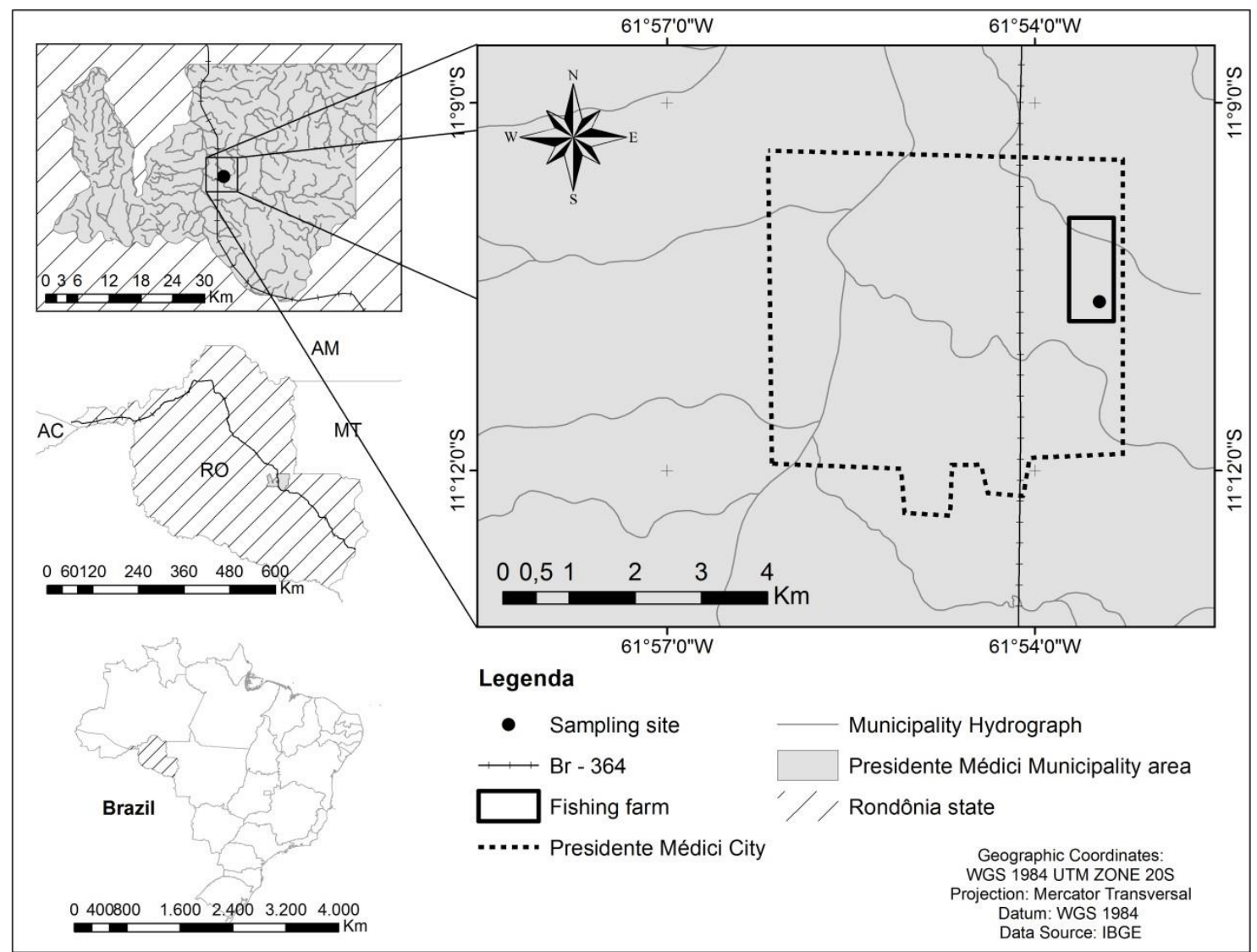

Figure 1. Geographic location of the experiment, Fishery Department at Universidade Federal de Rondônia in the municipality of Presidente Médici.

The tanks were drained to half of their total volume every 15 days for water renewal. During this moment, the biometry of $10 \%$ of the fish groups was performed. The total weight was measured with a digital scale (Balmak actlife) with precision of $0.001 \mathrm{~g}$. The fork length was measured with a millimeter ruler, whose observer's precision was $0.5 \mathrm{~cm}$. The performance indicators were estimated according to the description in Alatorre-Jacome, Garcia Trejo, Soto-Zarazua \& Rico-Garcia (2012). After 6, 9, and 12 farming months, 25 individuals were slaughtered in order to assess the fillet yield, following the equation below:

$\mathrm{FY}=(\mathrm{FW} / \mathrm{TW}) \times 100$, where: $\mathrm{FY}=$ Fillet Yield $(\%), \mathrm{FW}=$ Fillet weight $(\mathrm{g})$ and $\mathrm{TW}=$ total individual's weight.

In order to monitor the water quality, the temperature parameters, $\mathrm{pH}$, ammonia, DO (Dissolved Oxygen) and total alkalinity were verified every three days, at 06:00 a.m., 12:00, 06:00 p.m., and 00:00. These analyses were performed through visual comparison in a colorimetric card - ALFA KIT and the temperature was measured by a mercury thermometer.

The comparisons between the tanks were performed by using Student T-test (Blair \& Higgins, 1980; Mera, Thompson \& Prasad, 1999; Fay \& Proschan, 2010). The assumptions of normality and homoscedasticity were verified through Shapiro-Wilk and Levene Tests (Lim \& Loh, 1996; Yap \& Sim, 2011). The correlations between the water quality variables were analyzed by Pearson $r^{2}$ coefficient followed by Student's T-test for statistic significance (Edgell \& Noon, 1984). The statistic analyses were performed by using the software Statisoft Statistica 9.0 (Statsoft, 2009).

\section{Results and Discussion}

The performance indicators at the end of the experiment are shown in Table 1, and the growth curves in weight are illustrated in Figure 2. In spite of the differences observed in growth in months 5, 8, 10 and 11 $(\mathrm{p}<0.023)$, overall, the performance was similar between the tanks $(\mathrm{p}>0.979)$. 
Acta of Fisheries and Aquatic Resources

Table 1. Performance indicators in Colossoma macropomum tambaqui farming in excavated tanks without aeration (T1) and with mechanical aeration (T2). Averages values did not differ significantly when considering $\mathrm{p} \geq 0.05$ of probability.

\begin{tabular}{lccc}
\hline & $\mathrm{T} 1$ & $\mathrm{~T} 2$ & $p$ \\
\hline Final Weight $(\mathrm{g})$ & $1,956.80 \pm 440.22$ & $1,949.60 \pm 238.96$ & 0.943 \\
Biomass (kg) & 469.63 & 467.90 & 0.955 \\
Productivity (g/ m $\left.{ }^{2}\right)$ & 782.72 & 779.84 & 0.941 \\
Weight gain (g) & $1,915.83$ & $1,907.21$ & 0.889 \\
Growth rate (g/ day) & 5.82 & 5.80 & 0.994 \\
Specific growth rate (g/ day) & 1.18 & 1.16 & 0.994 \\
Metabolic growth rate (g/ day) & 5.83 & 5.82 & 0.997 \\
Fillet Yield (\%) & $56.66 \pm 2.99$ & $56.24 \pm 2.68$ & 0.464 \\
Apparent food conversion - AFC & 2.15 & 2.19 & 0.985 \\
\hline
\end{tabular}

The $\mathrm{p}$ values obtained from T-tests. A $1 \mathrm{HP}$ three-phase mechanical aerator was used, capable of injecting $2.5 \mathrm{Kg}$ of $\mathrm{O}_{2}$ per hour.

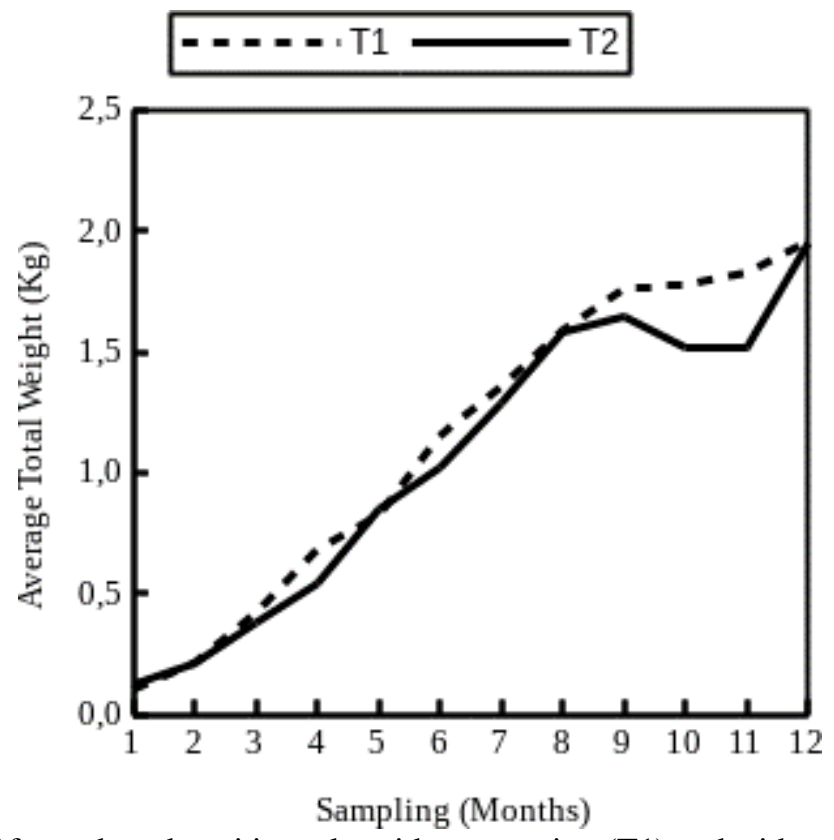

Figure 2. Weight growth of farmed tambaqui in tanks without aeration (T1) and with a mechanical aerator (T2).

The results from the water quality monitoring in the nurseries showed that in both excavated ponds, the DO and alkalinity variables remained above the minimum $(\mathrm{p}<0.001)$ Total ammonia remained below the limit $(\mathrm{p}<0.001)$ and the values of transparency, $\mathrm{pH}$, and temperature were within the recommended range $(p>0.106)$. When comparing the values of limnologic variables between the nurseries, it was verified that there were significant differences only for the values of dissolved oxygen, total ammonia and transparency $(\mathrm{p}=0.001)$. On the other hand, when analyzing the correlations among these variables, in both nurseries, alkalinity and temperature showed a low direct proportion $\left(r^{2}>0.012, p<0.039\right)$, the same was true for transparency and $\mathrm{pH}$ which showed a low inverse proportion $\left(\mathrm{r}^{2}>0.016, \mathrm{p}<0.017\right)$ (Table 2). 
Acta of Fisheries and Aquatic Resources

Table 2. Water quality in excavated tanks without aeration (T1) and with a mechanical aerator (T2).

\begin{tabular}{lcccc}
\hline Quality parameters & Reference values & $\mathrm{T} 1$ & $\mathrm{~T} 2$ & $p$ \\
\hline Dissolved Oxygen $(\mathrm{mg} / \mathrm{l})$ & $>4.0(1)$ & $7.82 \pm 0.98$ & $8.33 \pm 0.92$ & 0.001 \\
Total ammonia $(\mathrm{mg} / \mathrm{l})$ & $<1.0(2)$ & $0.29 \pm 0.31$ & $0.18 \pm 0.21$ & 0.001 \\
Transparency $(\mathrm{cm})$ & 30 to $60(1)$ & $63.50 \pm 14.07$ & $58.86 \pm 14.66$ & 0.001 \\
$\mathrm{pH}$ & 6.5 to $8.0(1)$ & $7.04 \pm 0.57$ & $7.11 \pm 0.71$ & 0.126 \\
Temperature $\left({ }^{\circ} \mathrm{C}\right)$ & 26 to $30(1)$ & $30.62 \pm 2.06$ & $30.45 \pm 2.03$ & 0.166 \\
Alkalinity $\left(\mathrm{mg} / 1 \mathrm{CaCO}_{3}\right)$ & $>20(3)$ & $28.26 \pm 6.10$ & $28.01 \pm 5.85$ & 0.248 \\
\hline
\end{tabular}

1: Kubitza (2003), 2: Conama (2005), 3: Sipaúba-Tavares (1994). p values obtained by using T-tests.

The results shown in Figure 2 and in Tables 1 and 2 that there is no aeration effect on the final performance, meat yield, and water quality in tambaqui farming. This result agrees with Pontes (2013), which obtained an increment of $30 \%$ in productivity with the use of aerators, but without any statistic significance. In the study, the author used a density of $0.19 \mathrm{fish} / \mathrm{m}^{2}(46.50 \%$ of the density adopted in the current study) and four 1.0 CV aerators, operating from 06:00 p.m. to 06:00 a.m. daily, in an experiment which lasted 120 days. On the other hand, Izelet al. (2013) obtained a productivity of $1,853 \mathrm{~g} / \mathrm{m}^{2}$, with an increase of $137.17 \%$ above what was obtained by Pontes (2013), and also showed a food conversion of 2.09. In order to do so, they used a density of 0.7 fish $\mathrm{m}^{2}$ (with $66.67 \%$ rate above the rate adopted in the current study) with four 1.5 HP aerators per hectare. The authors state that aeration enables the use of densities with greater stocks. Thus, it is possible to suspect that the aeration is good just when it is used together with high fish stock densities.

In the current study, water quality remained within the recommended range for tropical fish farming. However, it was observed the existence of a great amount of sediments in the ponds in periods of intercalation during the experiment. These sediments, in addition to being used as a potential means of toxic substances and the reason for damages to branchial epithelium (Esteves, 2011), it may have decreased the respiratory efficiency of the fish through metabolism reduction and oxygen ingestion (Val, Almeida-Val, Randal, 2006). However, as this phenomenon occurred with less intensity in T2 tank, it must not have caused any loss to the experiment. The difference in water transparency might have been a result of its own renewal, during the occurrences of biweekly biometries, since the drainage of $1 / 3$ of the water from the ponds in this procedure may have diluted the suspending particles in the tank water. On the other hand, this procedure also partly contributed to the improvement of water quality, especially with the reduction in concentration of total ammonia.

The apparent food conversion - AFC, of the experiment $(\mathrm{T} 1=2.15$ and $\mathrm{T} 2=2.19)$ was within the expected range for tambaqui farming during fattening stage, and it was in compliance with the other studies carried out with the species in the Amazon region, as shown by results of Izelet al. (2013) in tambaqui farming in excavated ponds by using aerators in the Amazonas state, where they obtained a 2.09 AFC. On the other hand, the studies in Rondônia state show average AFC values around $2.27 \pm 0.14$ in fattening stage, as reported in studies by Sousa et al., (2016) which reported an average food conversion of 2.51 for tambaqui juveniles under different stock densities, and finally, Sousa, Prado, Piñeyro \& Neto, (2016) and Neto, Prado, Prado \& Sousa (2017) who obtained AFC values of 2.21 and 2.42 followed by 2.17 and 2.27, respectively, when they tested different levels of raw protein in the food.

\section{Conclusions}

The use of aerator has no effect on tambaqui Colossoma macropomum farming in a semi-intensive production system. However, new studies are necessary for the verification of the effect of this equipment in intensive systems, with high fish stock density.

\section{Acknowledgements}

To CNPq for financial support, Universidade Federal de Rondônia for the logistic support and the facilities, and BIGSAL Nutrição Animal company, for the donation of food and a water analysis kit. To Mr. José Edilson Andrade for fish concessions. 


\section{References}

Alatorre-Jacome, O.; Garcia Trejo, F.; Soto-Zarazua \& Rico-Garcia, E (2012). Techniques to assess fish productivity in aquaculture farms and small fisheries: an overview of algebraic methods. Journal of Applied Sciences, 12(9): 888-892.

Batista, V.S. \& Petrere Jr., M. (2003). Characterization of the commercial fish production landed at Manaus, Amazonas State, Brazil. Acta Amazonica, 33(1): 53-66.

Blair, R.C. \& Higgins, J.J. (1980). A comparison of the power of Wilcoxon's Rank-Sum Statistic to that of Student's t Statistic under various non normal distributions. Journal of Educational Statistics, 5(4): 309335.

Bombardelli, R.A.; Syperreck, M.A. \& Sanches, E. A. (2005). Situação atual e perspectivas para o consumo, processamento e agregação de valor ao pescado. Arquivos de Ciências Veterinárias e Zoologia da UNIPAR, 8(2):181-195.

Boyd, C. (1998). Pond water aeration systems. Aquacultural Engineering, 18(1): 9-40.

Cartonilho, M.M. \& De Jesus, R.S. (2011). Qualidade de cortes congelados de tambaqui cultivado. Pesquisa agropecuária brasileira, 46(4): 344-350.

Castro, A.C. \& Souza, C.G.N.H. (2002). Avaliação do sistema de produção de Tambaqui intensivo em viveiro de terra com aeração. Embrapa, (EMBRAPA-CPATC).

Conama - Conselho Nacional do Meio Ambiente. Resolução no 357, de 17 de março de 2005. Disponível em: http://www.mma.gov.br/port/conama/res/res05/res35705.pdf.

Da Costa, A.L.S.; Tadeucci, M.S.R. \& Ricci, F. (2015). Caracterização da piscicultura na região de Ariquemes, no Estado de Rondônia/The characteristics of fish farming in Ariquemes Region, in Rondônia State. Campo-Território: Revista de Geografia Agrária, 10(20): 512-537.

Edgell, S.E. \& Noon, S.M. (1984). Effect of violation of normality on the $t$ test of the correlation coefficient. Psychological Bulletin, 95(3): 576-583.

El-Nemr, M.K. \& El-Nemr, M.K. (2013). Fish farm management and microcontroller based aeration control system. Agricultural Engineering International: CIGR Journal, 15(1): 87-99.

Esteves, F. A. (2011). Fundamentos de Limnologia. Rio de Janeiro: Interciência.

FAO, (2016). The State of World Fisheries and Aquaculture: Contributing to food security and nutrition for all.

Fay, M.P. \& Proschan, M.A. (2010). Wilcoxon-Mann-Whitney or t-test? On assumptions for hypothesis tests and multiple interpretations of decision rules. Statistics Surveys, 4: 1-39.

Freitas, R.S.; Boijink, C.L.; Muniz, A.W.; Daikiri, J.K. \& Inoue, L.A.K.A. (2014). Qualidade da água e perspectivas para gerenciamento ambiental dos cultivos de tambaqui no município de Rio Preto da Eva, AM. Scientia Amazonia, 3(1): 116-126.

Gomes, L.C. (2003). Protocolo para transporte de tambaqui Colossoma macropomum vivo. Manaus: Embrapa Amazônia Ocidental.

IBGE. (2015). Instituto Brasileiro de Geografia e Estatística. Coordenação de Agropecuária. Produção da Pecuária Municipal, 43: 1-49.

Izel, A.C.U. \& Melo, L.A.S. (2004). Criação de tambaqui (Colossoma macropomum) em tanques escavados no Estado do Amazonas. Manaus: Embrapa Amazônia Ocidental.

Izel, A.C.U.; Crescencio, R.; Almeida, F.L.; Chagas, E.C.; Boijink, C.L. \& Silva, J.I. (2013). Produção intensiva de tambaqui em tanques escavados com aeração. Manaus: Embrapa Amazônia Ocidental,. 4 p. (Circular Técnica, 39).

Kepenyes, J. \& Váradi, L. (1984).Aeration and oxygenation in aquaculture. In: Inland aquaculture Engineering. Aquaculture Development and Coordination Programe. 84(21): 473-50.

Kubitza, F. (2003). Qualidade da água na produção de peixes e camarões. Jundiaí: São Paulo.

Kubitza, F. (2004). Coletânea de informações aplicadas ao cultivo do tambaqui, do pacu e de outros peixes redondos. Panorama da Aquicultura. 14(82): 27-39.

Lim, T.S. \& Loh, W.Y. (1996). A comparison of tests of equality of variances. Computational Statistics \& Data Analysis, 22(3): 287-301.

Macedo, C.F. \& Sipaúba-Tavares, L.H. (2010). Eutrofização e qualidade da água na piscicultura: consequências e recomendações. Boletim Instituto da Pesca. 36(2): 149-163.

Maffezzolli, G. \& Nuñer, A.P.O. (2006). Crescimento de alevinos de jundiá, Rhamdia quelen (Pisces, Pimelodidae), em diferentes concentrações de oxigênio dissolvido. Acta Sci. Biol. Sci, 28(1): 41-45. 
Melo, L.A.S.; Izel, A.C.U. \& Rodrigues, F.M. (2001). Criação de tambaqui (Colossoma macropomum) em viveiros de argila/barragens no Estado do Amazonas. Manaus: Embrapa Amazônia Ocidental.

Mera, R.; Thompson, H.W. \& Prasad. C. (1999). Analysis of data that is in the form of categories. Nutritional Neuroscience, 2(5): 369-374.

Morais, I.S. \& O'Sullivan, F.L.A. (2017). Biologia, habitat e cultivo do tambaqui Colossoma macropomum (Cuvier, 1816). Scientia Amazonia, 6(1): 81-93.

Neto, E.B.B.; Prado, G.F.; Prado, G.A.F. \& Sousa, R.G.C. (2017). Engorda de tambaquis (1 a $3 \mathrm{~kg}$ ) arraçoados com dietas contendo 22 e $28 \%$ de proteína bruta. Scientia Amazonia, 6(1): 1-8.

Oliveira Sales, R. \& Maia, E.L. (2013). Composição química e classes de lipídios em peixe de água doce tambaqui, Colossoma macropomum. Revista Brasileira de Higiene e Sanidade Animal, 07(2): 31-44.

Pedroza-Filho, M.X.; Rodrigues, A.P.O. \& Rezende, F.P. (2016). Dinâmica da produção de tambaqui e demais peixes redondos no Brasil. CNA Brasil: Boletim Ativos da Aquicultura, 2(7): 1-5. Brasília.

Pontes, M.F. (2013). Efeito da aeração artificial suplementar sobre a produtividade do tambaqui (Colossoma macropomum) em sistema sem fluxo contínuo de água [Dissertação de Mestrado]. Manaus (AM): Universidade Federal do Amazonas.

Silva, A.D.R.; Santos, R.B.; Bruno, A.M.S.S.; Gentelini, A.L.; Silva, A.H.G. \& Soares, E.C. (2014). Eficiência do aguapé sobre variáveis limnológicas em canais de abastecimento utilizados no cultivo de tambaqui. Acta Amazonica, 44(2): 255-262.

Silva, C.A. (2015). Boas práticas de manejo na criação de tambaquis em tanques-rede. Aracaju: Embrapa Tabuleros Costeiros.

Sipaúba-Tavares, L.H. (1994). Limnologia aplicada à aquicultura. Jaboticabal: Funep.

Sousa, R.G.C.; Piñeyro, J.I.G.; Cardoso, N.A.; Andrade, J.E.; Da Silva, J.G. \& Barbosa, H.T.B. (2016). Stocking density and its effects to the zootechnical development of young tambaqui in an intensive production system. Acta of Fisheries and Aquatic Resources, 4(1): 80-92.

Sousa, R.G.C.; Prado, G.F.; Piñeyro, J.I.G. \& Neto, E.B.B. (2016). Avaliação do ganho de peso do tambaqui cultivado com diferentes taxas de proteínas na alimentação. Biota Amazdo g, 6(1): 40-45.

Statsoft, Inc. (2009). Statistica (data analysis software systems), version 9.0. www.statsoft.com

Thakre, S.B.; Bhuyar, L.B. \& Deshmukh, S.J. (2008). Effect of different configurations of mechanical aerators on oxygen transfer and aeration efficiency with respect to power consumption. International Scholarly and Scientific Research \& Innovation, 2(2): 170-178.

Val, A.L.; Almeida-Val, V.M.F. \& Randal, D.J. (2006). The physiology of tropical fishes (Fish Physiology Series). London, UK: Elsevier (Academic Press).

Vinatea, L. (2004). Princípios químicos de qualidade da água em aquicultura. Florianópolis: UFSC.

Yap, B.W. \& Sim, C.H. (2011). Comparisons of various types of normality tests. Journal of Statistical Computation and Simulation, 81(12): 2141-2155. 